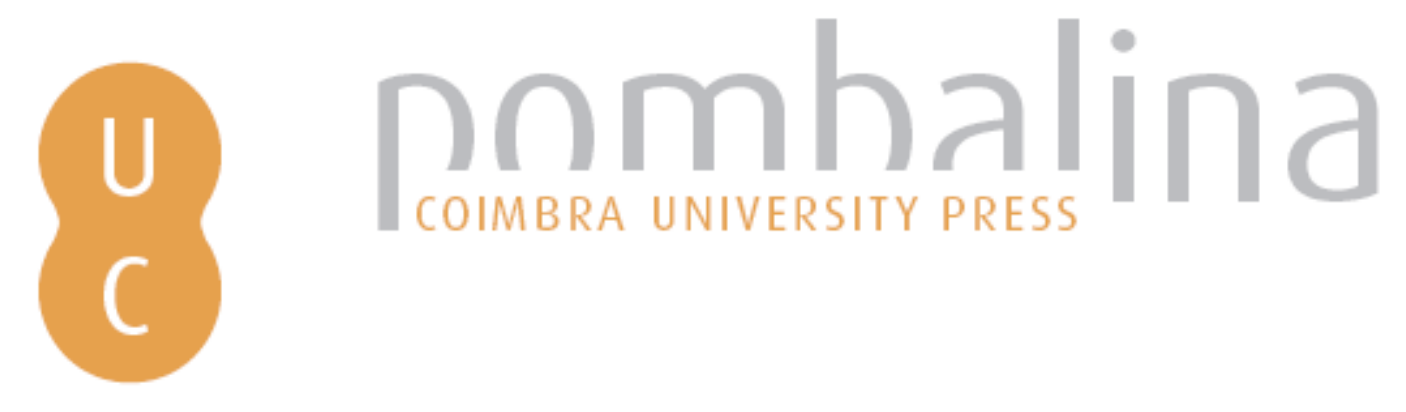

\title{
"Estados Unidos e Europa: entre parceria e isolacionismo": uma visão desde os Estudos Europeus
}

\author{
Autor(es): $\quad$ Sebastião, Dina \\ Publicado por: Imprensa da Universidade de Coimbra \\ URL \\ persistente: URI:http://hdl.handle.net/10316.2/47309 \\ DOI: $\quad$ DOI:https://doi.org/10.14195/978-989-26-1849-4_18 \\ Accessed : $\quad$ 26-Apr-2023 15:19:09
}

A navegação consulta e descarregamento dos títulos inseridos nas Bibliotecas Digitais UC Digitalis, UC Pombalina e UC Impactum, pressupõem a aceitação plena e sem reservas dos Termos e Condições de Uso destas Bibliotecas Digitais, disponíveis em https://digitalis.uc.pt/pt-pt/termos.

Conforme exposto nos referidos Termos e Condições de Uso, o descarregamento de títulos de acesso restrito requer uma licença válida de autorização devendo o utilizador aceder ao(s) documento(s) a partir de um endereço de IP da instituição detentora da supramencionada licença.

Ao utilizador é apenas permitido o descarregamento para uso pessoal, pelo que o emprego do(s) título(s) descarregado(s) para outro fim, designadamente comercial, carece de autorização do respetivo autor ou editor da obra.

Na medida em que todas as obras da UC Digitalis se encontram protegidas pelo Código do Direito de Autor e Direitos Conexos e demais legislação aplicável, toda a cópia, parcial ou total, deste documento, nos casos em que é legalmente admitida, deverá conter ou fazer-se acompanhar por este aviso.

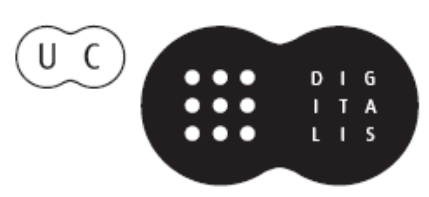


Euro-Atlântico:

Espaço de Diálogos

Isabel Maria Freitas Valente

Iranilson Buriti de Oliveira

(Coord)

\section{VISÕES \\ INTERDISCIPLINARES \\ DA EUROPA \\ E DO MUNDO:}

uma experiência de convergência

disciplinar em homenagem a

Maria Manuela Tavares Ribeiro

Alexandra Aragão

Isabel Maria Freitas Valente

Dulce Lopes

(org.)

Editora da Universidade Federal de Campina Grande

Imprensa da Universidade de Coimbra

2019 


\section{"ESTADOS UNIDOS E EUROPA: ENTRE PARCERIA E ISOLACIONISMO”, UMA VISÃO DESDE OS ESTUDOS EUROPEUS}

Dina Sebastião

Esta interessante reflexão historiográfica das relações internacionais entre EUA e Europa suscita-nos o aprofundamento de algumas linhas temáticas tocadas no texto, numa abordagem comparativa entre conjunturas históricas semelhantes, analisando com particularidade o posicionamento europeu, quer na perspetiva diferenciada dos Estados, quer na conjunta da UE, e/ou de conjuntos de Estados na UE. Fundamentamos a seguir algumas sugestões:

- Considerando o regresso dos EUA ao isolacionismo após a Primeira Guerra Mundial, consolidado com a rejeição da entrada na Sociedade das Nações, e atentando à particular conjuntura política da crise de 1929, com a eclosão de nacionalismos e ascensão de fascismos na Europa, toma-se como pertinente a investigação numa perspetiva comparativa com a conjuntura pós-crise financeira de 2007/2008, tendo em consideração o subsequente crescimento de tendências políticas nacionalistas, populistas e iliberais na Europa (salvaguardando que não se pretende considerar que o crescimento de partidos populistas e nacionalistas se deva exclusivamente à crise). Pode investigar-se detalhadamente a orientação da política externa das administrações dos EUA - e o debate político interno em torno dela - relativamente às evidências de um indício de desintegração da UE e de fragmentação política na Europa pós-2008, realçando-se a pertinência de considerar a perspetiva historiográfica na investigação, tendo como variáveis comparativas a inexistência/existência de unidade europeia (UE) e a política externa soviética/russa face à Europa.

- Investigação sobre o papel da China na ponderação das relações bilaterais EUA - UE e na potencial (re)valorização da unidade europeia

- quer dos EUA para com a UE, quer desta no incremento das relações com os EUA. Perspetiva-se esta abordagem de investigação 
levantando-se a possibilidade do aumento de interesse mútuo num reforço das relações bilaterais, com o objetivo de manter a capacidade de influência ocidental no sistema internacional, tendo em conta o evidente trajeto de hegemonização da China no (ainda) sistema multilateral das relações internacionais (influenciando as diplomacias nacionais através da influência económica, ganhando sobretudo um predomínio considerável no Sul da Europa e em África).

- Investigação da influência que a (aparente) volatilidade das últimas presidências norte-americanas para com a NATO e a UE, particularmente com as crises nas relações comerciais transatlânticas, tem tido nas perceções e atuação políticas europeias sobre a Política Externa e de Segurança Comum (PESC) e da Política Comum de Segurança e Defesa (PCSD). Considera-se importante integrar nesta análise a variável Brexit. Enquadra-se neste estudo a aferição de diversas perspetivas: os diferentes posicionamentos políticos nacionais na UE, nomeadamente entre os países atlantistas (favoráveis a uma PESC intergovernamental, conciliável com o predomínio da soberania nacional e consequentemente com a primazia à NATO como principal aliança de defesa europeia) e os países europeístas/continentalistas (favoráveis a uma evolução supranacional da PESC, com efetiva capacitação política e operacional da UE na área da segurança e defesa - embora mantendo a parceria com a NATO, mas dando autonomização de ação à UE).

No fundo, o que aqui se sugere são fragmentos vários, que decorrem do aprofundamento de algumas abordagens disciplinares já evidentes no texto do autor, como a das RI e historiográfica, e que concorrem para um estudo integrado e comparativo sob dois ângulos de análise da atualidade das relações EUA - Europa: a) ver as relações EUA/Europa/ UE numa perspetiva historiográfica de profunda alteração do sistema internacional desde o pós-Segunda Guerra Mundial - tentando aferir se entre os cambiantes existe uma transversalidade de motivações (renovadas) para manter a coesão da relação transatlântica; 
b) problematizar, sob a perspetiva interdisciplinar dos Estudos Europeus a atual condição intergovernamentalista da PESC e PCSD como "prisioneiras" da historicidade de uma relação transatlântica, e perspetivar nessa relação em permanente revisão perspetivas futuras para uma evolução (supranacional) destas políticas europeias. 